\title{
ALUNOS NO COMÉRCIO E A TAXA DE JUROS: a construção de conceitos de progressões aritméticas e geométricas
}

ROBERTA NARA SODRÉ DE SOUZA'

\section{Introdução}

Nos dias em que vivemos, o consumidor de pequeno e médio porte procura cada vez mais as financiadoras e lojas que possuem financiamentos a perder de vista para adquirir bens de consumo duráveis. $\mathrm{O}$ consumidor geralmente não possui um conhecimento para verificar se os juros cobrados são realmente aplicados, então desde que a prestação se encaixe em seu orçamento não se preocupa, em verificar o preço final, tampouco se o juro cobrado é realmente aquele que está sendo divulgado.

A partir da preocupação colocada acima, de reportagens divulgadas na imprensa sobre a cobrança indevida de juros por concessionárias de carros em São Paulo e da necessidade que senti, enquanto educadora, de inserir a matemática deste nível de ensino de forma contextualizada e inerente aos problemas cotidianos enfrentados pelos cidadãos, nasceu um projeto de ensino e uma proposta didática para o desenvolvimento dos conceitos de progressões, geométricas e aritméticas no $1^{\circ}$ ano do Ensino Médio no ano de 2002 no Colégio de Aplicação da Univali.

1 Mestre em Educação pela Univali. Professora de Matemática no Ensino Médio do Colégio de

Aplicação da Univali. E-mail: roberta@cehcom.univali.br 


\section{Objetivos do projeto e metodologia}

Enquanto objetivo do projeto, junto com o grupo de 95 alunos, tínhamos como interesse identificar se os juros cobrados pelo comércio e financiadoras da cidade eram os mesmos que os divulgados a seus consumidores. Enquanto professora, objetivava por meio das habilidades cálculo e discussões teóricas com os alunos significar os conceitos de progressões aritméticas e geométricas relacionando-os ao cálculo dos juros.

Inicialmente, os alunos fizeram em equipes um levantamento de dados, em todo o comércio da cidade e nos mais diversos setores, recolhendo os preços a vista, a prazo e os juros cobrados nas compras a prazo (televisores, vídeo-cassete, máquina de lavar roupa, geladeiras, automóveis, motos, materiais de construção, bancos de crédito, produtos de náutica). Voltando a sala com os dados, observamos que nas compras com maior prazo, os comerciantes utilizavam uma tabela e a partir dela faziam os cálculos, outros, principalmente nas compras com prazos pequenos, não cobravam juros e ou aplicavam os juros simples. Os alunos também registraram a falta de interesse de alguns comerciantes atendê-los com interesse. A partir do que foi levantado pelos alunos nos dados, surgiram outros pontos de interesse para descobrirmos: qual é a diferença dos tipos de juros; como é feita essa tabela. Baseando-se nas dúvidas que surgiram após a coleta, convencemos os alunos da necessidade de um estudo teórico sobre os diferentes tipos de juros e iniciamos essa discussão a partir dos conceitos de progressões aritméticas e geométricas.

\section{Como desenvolvemos a parte teórica}

O desenvolvimento da parte teórica se deu sempre vinculando as progressões, as funções e aos juros, fazendo um ir e vir nos exemplos aplicados, para que os alunos pudessem perceber que os conceitos estudados se relacionavam e que posteriormente pudessem verificar através de que processo de juros os comerciantes se baseavam e se estavam corretos. Nas discussões, percebemos que a variação de juros simples para compostos mostra uma relação bem diferente, no primeiro os valores crescem somando um número constante à razão e no segundo multiplicando um número constante. Por isso, dizemos que para calcular o montante aplicado a juros compostos temos uma função exponencial e uma progressão geométrica e para o cálculo dos juros simples uma função afim e uma progressão aritmética. Podemos mostrar a inter-relação dos conceitos, observando 
que o montante $\mathrm{M}$ obtido após a aplicação de uma quantia em dinheiro num determinado tempo (t) é uma função do tipo afim ou do $1^{\circ}$ grau.Vejamos:

$$
\mathrm{Y}=\mathrm{ax}+\mathrm{b} \text { e } \mathrm{M}=\mathrm{C}+\mathrm{j} . t \text { (onde } \mathrm{C} \text { é o capital e j é o juros em reais) }
$$

Num exemplo de um empréstimo de R $\$ 1000,00$ por um determinado tempo t, com taxa de $3 \%$ a juros simples, teríamos a função:

$$
M=1000+30 . t
$$

Isto nos remete a ver a relação com as progressões aritméticas:

$$
A n=a 1+(n-1) \cdot r \text { (fórmula do termo geral de uma P.A) }
$$

Onde a nossa razão seria o j e nosso a1 seria os $\mathrm{R} \$ 1000,00$, o an seria o M, montante após o tempo da aplicação. Percebemos na evolução mensal, uma soma de 30 reais ao valor anterior da seqüência, por esse motivo os juros simples são funções afins e progressões aritméticas, já que temos uma seqüência onde a regularidade é percebida pela soma de uma parcela constante que caracteriza a razão da P.A.

Já os juros compostos é juros sobre juros, a variação do montante em função do tempo t se dará de forma exponencial segundo uma progressão geométrica, já que temos uma seqüência onde a regularidade é obtida por meio de uma multiplicação de um número (razão) pela primeira parcela.Vejamos:

$$
\begin{aligned}
& F(x)=a^{x} \quad \text { (função exponencial) } \\
& M=C \cdot(1+i)^{t} \text { (função dos juros compostos) } \\
& i=\text { taxa de juros }
\end{aligned}
$$

No exemplo do empréstimo de $\mathrm{R} \$ 1000,00$ agora sob juros compostos teríamos:

$$
\mathrm{M}=1000.1,03 \mathrm{t}
$$

Agora, observe a fórmula dela:

$$
\text { an=a1.q }{ }^{\mathrm{n}-1} \text { (fórmula do termo geral de uma P.G.) }
$$

O an é o Montante o al é o dinheiro inicial da aplicação o q a taxa de juros e o n-1 o tempo.

Observe as progressões formadas para o exemplo de um empréstimo de $\mathrm{R} \$$ 1000,00: 


\begin{tabular}{|c|c|c|}
\hline Tempo & Montante (juros simples) P.A & Montante (juros compostos) P.G. \\
\hline 0 & 1000 & 1000 \\
1 & 1030 & 1030 \\
2 & 1060 & 1060,9 \\
3 & 1090 & 1092,73 \\
4 & 1120 & 1125,51 \\
5 & 1150 & 1159,27 \\
\hline
\end{tabular}

Além de mostrar aos alunos a relação da tabela mostrei também no gráfico, onde ficou mais visível a diferença entre o crescimento exponencial de uma progressão geométrica para o crescimento linear de uma progressão aritmética. A partir disso desenvolvemos exemplos práticos conferindo os dados que eles recolheram no comércio de nossa cidade. Depois da discussão os alunos observaram que alguns exemplos não conferiam nem por juros simples e nem por compostos, então discutimos a questão da amortização dos juros sobre as parcelas já quitadas e vimos de onde surgiam as tabelas que estavam nas mãos dos vendedores quando solicitavam o valor de um produto a prazo.

Posteriormente ao desenvolvimento dos das questões teóricas que se relacionavam as dúvidas encontradas quando da coleta de dados, os alunos voltaram-se para os dados recolhidos sobre o comércio que cada equipe foi investigar, colocando as habilidades de cálculo sobre juros e então sobre as progressões em prática e verificando se em algum comércio existia um superfaturamento do que era divulgados aos consumidores.

\section{O feedback para os comerciantes pelos alunos}

Com apresentações ao grande grupo, os alunos, divulgaram o que encontraram em cada comércio relacionando se existia ou não erro relacionado ao que estava sendo divulgado aos consumidores e posteriormente cada aluno desenvolveu um relatório final contendo uma visão geral sobre o problema que foi investigado. Fizemos uma exposição no colégio sobre nossos resultados.

Em relação às conclusões tiradas podemos identificar alguns setores cobram a mais dos consumidores. Observamos também que alguns comércios divulgam de forma errada ao cliente, cobrando um preço inferior à porcentagem divulgada, outros não consideram o código de defesa do consumidor quando divulgam que o preço à vista é o mesmo do preço a prazo. Os alunos observaram a importância de alertar todos os consumidores e empresários, em relação à cobrança indevida de juros, até porque isso pode gerar grandes prejuízos para ambas as partes. 


\section{A experiência me fez mais educadora}

Enquanto professora e orientadora do projeto, considero que a metodologia empregada para o desenvolvimento dos conceitos de progressões aritméticas e geométricas foi gratificante, me fez mais educadora. Foi um desafio, uma experiência nova, relacionar os conceitos a serem desenvolvidos vinculando-os a problemas enfrentados no cotidiano de um cidadão e procurando discutir essa dialética com o aluno. De tal forma que a pergunta muito comum de ser ouvida pelos alunos do Ensino Médio em Matemática: "Para que vou usar isso?", desapareceu no ano letivo. Acredito que o aluno pode perceber que a disciplina específica, no caso a Matemática, não é um mundo composto de gavetas e que os conceitos se relacionam entre si e com o cotidiano. Novas vivências de relacionamento harmônico com os alunos foram estabelecidas, um olhar sobre o novo, sobre o diferente, sobre as habilidades dos alunos que vão além da formação de conceitos para a construção do sujeito crítico que pode intervir sobre problemas. 